\title{
Pharmacokinetics of orally administered simvastatin in turkeys
}

\author{
A. Jasiecka ${ }^{1}$, T. Grabowski ${ }^{2}$, T. Maślanka ${ }^{1}$, H. Ziółkowski ${ }^{1}$, J.J. Jaroszewski ${ }^{1}$ \\ 1 Departament of Pharmacology and Toxicology, Faculty of Veterinary Medicine, \\ University of Warmia and Mazury, Oczapowskiego 13, 10-718 Olsztyn, Poland \\ ${ }^{2}$ Polpharma Biologics, Trzy Lipy 3, 80-172 Gdańsk, Poland
}

\begin{abstract}
The aim of the present study was to determine the pharmacokinetics of simvastatin (SIM) administered orally in 6-week-old turkeys at a single dose of $2 \mathrm{mg} / \mathrm{kg}$ b.w. The SIM concentrations in plasma were determined by validated HPLC-MS/MS method. Mean $( \pm$ SD; $n=10)$ values of pharmacokinetic parameters evaluated were as follows: $\mathrm{C}_{\max }=0.49 \pm 0.21 \mathrm{ng} / \mathrm{ml}, \mathrm{t}_{\max }=1.6 \pm 1.1 \mathrm{~h}$, $\mathrm{AUC}_{(0-\infty)}=1.08 \pm 0.57 \mathrm{~h} \times \mathrm{ng} / \mathrm{ml}, \mathrm{t}_{1 / 2 \mathrm{kel}}=2.14 \pm 1.3 \mathrm{~h}$ and $\mathrm{MRT}=3.08 \pm 1.52 \mathrm{~h}$. The results indicate that the SIM is absorbed from the gastrointestinal tract of turkeys; however, achieved plasma level is lower compared to those observed in mammals.
\end{abstract}

Key words: simvastatin, pharmacokinetics, HPLC, turkey

\section{Introduction}

Simvastatin (SIM) is a reversible inhibitor of the microsomal enzyme 3-hydroxy-3-methylglutaryl-coenzyme A (HMG-CoA) reductase, widely used in the treatment of various types of hypercholesterolemia (Lupattelli et al. 2012). The SIM is pharmacologically inactive lactone (prodrug form) which is absorbed from the stomach and largely converted to several active metabolites in the liver (Jang et al. 2010). The HMG-CoA reductase inhibitors (also called statins) are known to decrease plasma cholesterol by inhibition of cholesterol biosynthesis. Elkin et al. (1999) showed that SIM reduced egg cholesterol contents in laying hens as well as liver and plasma cholesterol concentrations. Due to the significant contribution of cholesterol in the pathogenesis of atherosclerosis and coronary heart disease, it appears likely that the production of poultry eggs with reduced cholesterol content may be one of the elements of prevention and therapy of these diseases. SIM and other statins appear to be potential candidates for a feed additive for obtaining food products of animal origin with reduced cholesterol content. However, to our knowledge, the available literature contains no data on the pharmacokinetic profile of SIM in poultry. Therefore, the aim of this study was to investigate the pharmacokinetics of SIM after oral administration of a single dose of the drug in turkeys.

\section{Materials and Methods}

The study was performed on 6-week-old female turkeys $(\mathrm{n}=13)$. The birds were clinically healthy,

Correspondence to: J. Jaroszewski, e-mail: jerzyj@uwm.edu.pl, tel.: +48 895233758 
housed and treated in accordance with the rules approved by the Local Ethics Commission (Approval No. 38/2010). SIM (Zocor ${ }^{\circledR} 20$, Merck, USA) at a dose of $2 \mathrm{mg} / \mathrm{kg}$ b.w. was administered directly into the crop by silastic tube (tablets were crushed and dissolved in water) in 10 birds. Heparinized blood samples were collected from the brachial vein before SIM administration and at 0.25, 0.5, 1, 1.5, 2, 2.5, 3, 3.5, 4, 4.5, 6, 12 $\mathrm{h}$ after drug administration. Plasma was separated by centrifugation $\left(1200 \times \mathrm{g}, 10 \mathrm{~min}, 4^{\circ} \mathrm{C}\right)$ and stored at $-21^{\circ} \mathrm{C}$ until analysis. Plasma extraction samples were analyzed using Alliance Waters 2695 and Quattro micro API MS (Waters Corporation, USA). An indapamide (Sigma-Aldrich, Germany) was used as internal standard (IS). All solvents used were of HPLC grade. Chromatographic separation was performed using an Acquity BEH C8 $(1.7 \mu \mathrm{m}, 50 \times 2.1 \mathrm{~mm})$ column (Waters Corporation) by gradient elution with a flow rate of $0.35 \mathrm{ml} / \mathrm{min}$ at temp. $50^{\circ} \mathrm{C}$. Mobile phase A consisted of $0.01 \mathrm{M}$ ammonium acetate $(\mathrm{pH}$ $=4$ ) and mobile phase B consisted of acetonitryle. The volume of injection was $10 \mu$ l. Detection was done at multiple reaction monitoring of $441.0 \rightarrow 325.2$ and $365.0 \rightarrow 132.0$ for SIM and IS, respectively. The peak area was measured and the peak area ratio of drug to internal standard and the concentration were calculated using MassLynx 4.1 software (Waters Corporation). Pharmacokinetic analysis was performed in a non-compartmental model using WinNonLin 6.0 Professional software (Pharsight Corporation).

\section{Results and Discussion}

The method was validated according to Food and Drug Administration (FDA) requirements (FDA 2001) and the results were as follows: linearity -0.1 $-30.7 \mathrm{ng} / \mathrm{ml}$, RSD \% of precision -9.72 , RSD\% accuracy -6.4 , recovery $-52.66 \%$, and matrix effect - 9.6\%. The lowest limit of quantification was 0.1 $\mathrm{ng} / \mathrm{ml}$.

Fig. 1 shows mean $( \pm \mathrm{SD})$ concentrations of SIM in plasma of turkeys and Table 1 shows mean $( \pm$ SD) values of selected pharmacokinetic parameters. Due to the lack of data on the pharmacokinetics of SIM in birds our results have been discussed with the data obtained in studies in humans and pigs. In humans, after a single administration of SIM at a dose of $40 \mathrm{mg}$ (approximately $0.6 \mathrm{mg} / \mathrm{kg}$ b.w.) maximum plasma concentration $\left(\mathrm{C}_{\max }\right)$ reached a value of $3.24 \mathrm{ng} / \mathrm{ml}$ (Najib et al. 2003) or $5.69 \mathrm{ng} / \mathrm{ml}$ (Jang et al. 2010), while time to achieve $\mathrm{C}_{\max }\left(\mathrm{t}_{\max }\right)$ was $1.8 \mathrm{~h}$ (Najib et al. 2003) or $1.71 \mathrm{~h}$ (Yang et al. 2010). In pigs, after a single SIM administration at a dose of $0.25 \mathrm{mg} / \mathrm{kg} \mathrm{C} \mathrm{max}_{\max }$ reached a value of $67.7 \mathrm{ng} / \mathrm{ml}$, and $\mathrm{t}_{\max }$ was $1.5 \mathrm{~h}$ (Cermak et al.
2009). In our study, despite the use of a higher dose than those used in humans or in pigs, the mean $\mathrm{C}_{\max }$ $(0.49 \mathrm{ng} / \mathrm{ml})$ was repeatedly lower, although the value of $t_{\max }(1.6 \mathrm{~h})$ was similar. Probably such large discrepancies in $\mathrm{C}_{\max }$ are a consequence of lower bioavailability and/or higher first pass effect of SIM in the turkey compared to mammals. The mean value of elimin-

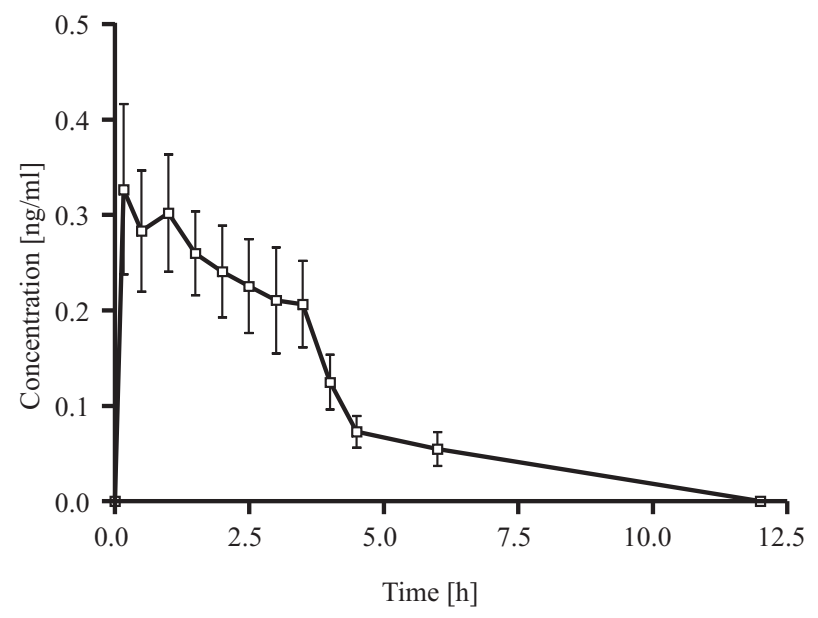

Fig. 1. Mean $( \pm \mathrm{SD} ; \mathrm{n}=10)$ plasma concentration of simvastatin in turkey plasma after drug administration into the crop at a dose of $2 \mathrm{mg} / \mathrm{kg}$ b.w.

Table 1. Pharmacokinetic parameters of simvastatin in turkey after oral drug administration at a dose of $2 \mathrm{mg} / \mathrm{kg}$ of body weight.

\begin{tabular}{lc}
\hline \multicolumn{1}{c}{ Parameter } & Mean $\pm \mathrm{SD}$ \\
\hline $\mathrm{C}_{\max }(\mathrm{ng} / \mathrm{ml})$ & $0.49 \pm 0.21$ \\
$\mathrm{t}_{\max }(\mathrm{h})$ & $1.6 \pm 1.1$ \\
$\mathrm{t}_{1 / 2 \mathrm{kel}}(\mathrm{h})$ & $2.14 \pm 1.3$ \\
$\mathrm{AUC}(0-8)(\mathrm{h} \backslash \mathrm{ng} / \mathrm{ml})$ & $1.08 \pm 0.37$ \\
MRT $(\mathrm{h})$ & $2.22 \pm 0.46$ \\
\hline
\end{tabular}

$\mathrm{C}_{\max }$ - maximum plasma concentration; $\mathrm{t}_{\max }$ - time to achieve $\mathrm{C}_{\max } ; \mathrm{t}_{1 / 2 \mathrm{kel}}$ - elimination half-life; $\mathrm{AUC}_{(0-\infty)}$ - area under the curve extrapolated to infinity; MRT - mean residence time.

ation half - life $\left(\mathrm{t}_{1 / 2 \mathrm{kel}}\right)$ of SIM in turkey was $2.14 \mathrm{~h}$, while $\mathrm{t}_{1 / 2 \mathrm{kel}}$ in humans reached a value of $2.8 \mathrm{~h}$ (Najib et al. 2003) or $5.85 \mathrm{~h}$ (Jang et al. 2010), and in pigs $\mathrm{t}_{1 / 2 \mathrm{kel}}$ was $4.46 \mathrm{~h}$ (Cermak et al. 2009). Thus, the value of $t_{1 / 2 \mathrm{kel}}$ obtained in turkey was also lower compared to the data from humans or pigs, but the differences were not so large as compared to the differences in $\mathrm{C}_{\max }$. In a previous study reduction of cholesterol level in eggs was observed in laying hens treated with SIM at a daily dosage of $60 \mathrm{mg} / \mathrm{hen}$ (Elkin et al. 1999). The obtained results suggest that for effective reduction of cholesterol level in products of poultry origin much more higher doses of SIM should be used compared to those used in humans. 


\section{References}

Cermak R, Wein S, Wolffram S, Langguth P (2009) Effects of the flavonol quercetin on the bioavailability of simvastatin in pigs. Eur J Pharm Sci 38: 519-524.

Elkin RG, Yan Z, Zhong Y, Donkin SS, Buhman KK, Story JA, Turek JJ, Porter RE Jr, Anderson M, Homan R, Newton RS (1999) Select 3-hydroxy-3-methylglutaryl-coenzyme A reductase inhibitors vary in their ability to reduce egg yolk cholesterol levels in laying hens through alteration of hepatic cholesterol biosynthesis and plasma VLDL composition. J Nutr 129: 1010-1019.

FDA and CDER. Guidance for Industry: Bioanalytical Method Validation. US Department of Health and Human Services, Food and Drug Administration, Center for Drug Evaluation and Research: Rockville, MD (2001).
Jang SB, Lee YJ, Lim LA, Park KM, Kwon BJ, Woo JS, Kim YI, Park MS, Kim KH, Park K (2010) Pharmacokinetic comparison of controlled-release and immediate-release oral formulations of simvastatin in healthy Korean subjects: a randomized, open-label, parallel-group, singleand multiple-dose study. Clin Ther 32: 206-216.

Lupattelli G, Siepi D, De Vuono S, Roscini AR, Crisanti F, Covelli D, Pirro M, Mannarino E (2012) Cholesterol metabolism differs after statin therapy according to the type of hyperlipemia. Life Sci 90: 846-850.

Najib NM, Idkaidek N, Adel A, Admour I, Astigarraga RE, Nucci GD, Alam SM, Dham R, Qumaruzaman (2003) Pharmacokinetics and bioequivalence evaluation of two simvastatin $40 \mathrm{mg}$ tablets (Simvast and Zocor) in healthy human volunteers. Biopharm Drug Dispos 24: 183-189. 